of authority - exemplified by Re St Peter, Church Lawford [2016] ECC Cov 3 required a substantial reason to be shown before a faculty would be granted for a memorial which fell outside the scope of the diocesan churchyard regulations and could not therefore be authorised otherwise than by faculty.

The chancellor held that, as there was no statutory basis for churchyard regulations, it was open to different chancellors to take different approaches when it came to petitions for memorials that could not be authorised by incumbents under regulations that each chancellor had made for his or her respective diocese. The approach previously taken in the Diocese of Coventry was taken by a number of chancellors and was a legitimate one: it was fair to those who had chosen memorials that came within the scope of churchyard regulations to require those who did not do so to show a good reason; and it reflected the role of regulations in expressing an understanding of what was generally acceptable and appropriate. Accordingly, the chancellor would continue to follow the approach he had indicated in Re St Peter, Church Lawford. [Alexander McGregor]

doi:10.1017/So956618X18000789

\title{
Re St Luke, Middlestown
}

Leeds Consistory Court: Hill Ch, 5 February 2018

[2018] ECC Lee 1

Pews and chairs - DAC advice

The churchwarden and priest-in-charge of this unlisted church built in 1974 sought a faculty for the removal of the pews and their replacement with timberframed upholstered chairs. The Diocesan Advisory Committee (DAC) did not recommend the proposal, stating that the chairs were heavy and difficult to stack and that the dark upholstery would be detrimental to the light levels and appearance of the church. The Church Buildings Council did not wish to comment on the proposals as the church is unlisted. On a site visit the chancellor noted that the same chair had been introduced into a neighbouring church and it had worn well and was easy to stack and unstack. He observed the light levels within the church and queried whether the DAC's view might have been different if a site visit had taken place. The chancellor observed that considerable weight should be afforded to the expertise and experience of the DAC in the exercise of its statutory duty, but that the chancellor could not fetter his discretion by routinely rubber-stamping DAC advice. The chancellor was independent of the diocese and must take account of all relevant material and all applicable law. The faculty was granted. [RA] 